Expl Agric. (2019), volume 55 (2), pp. 251-272 (C) Cambridge University Press 2018. This is an Open Access article, distributed under the terms of the Creative Commons Attribution licence (http://creativecommons.org/licenses/by/4.0/), which permits unrestricted re-use, distribution, and reproduction in any medium, provided the original work is properly cited.

doi: $10.1017 /$ S0014479718000066

\title{
PERENNIAL GRAINS FOR AFRIGA: POSSIBILITY OR PIPEDREAM?
}

\author{
By SIEGLINDE SNAPP† $\ddagger$, PAUL ROGÉ $\ddagger$, PATRICK OKORI§, \\ REGIS CHIKOWO $\dagger$, BRAD PETER $\ddagger$ and JOSEPH MESSINA \\ $\dagger$ Department of Plant, Soil and Microbial Sciences, Michigan State University, East Lansing, MI \\ 48824, USA, $\ddagger$ Center for Global Change $\&$ Earth Observations, Michigan State University, East \\ Lansing, MI 48824, USA and §Iternational Crops Research Institute for the Semi-arid Tropics, \\ Lilongwe 3, Malawi
}

(Accepted 9 January 2018; First published online 12 April 2018)

\begin{abstract}
SUMMARY
Perennial grain crops have been proposed as a transformative approach to agriculture. Replacing annual staple crops with perennialized growth types of the same crops could provide environmental services, improve labour efficiency and weather resilience, reduce seed costs and produce livestock fodder or fuelwood production. Yet, the technologies and science for agricultural development in Africa have focused almost exclusively on annuals. In this paper, we review the literature to explore what has been potentially overlooked, including missed opportunities as well as the disadvantages associated with perennial grains. The case studies of pigeon pea and sorghum are considered, as an analogue for perennial grain crops in Africa. We find that a substantial number of farmers persist in 'perennializing' pigeon pea systems through ratoon management, and that sorghum ratoons are widely practiced in some regions. In contrast, many crop scientists are not interested in perennial traits or ratoon management, citing the potential of perennials to harbour disease, and modest yield potential. Indeed, an overriding prioritization of high grain yield response to fertilizer, and not including accessory products such as fodder or soil fertility, has led to multipurpose, perennial life forms being overlooked. Agronomists are encouraged to consider a wide range of indicators of performance for a sustainable approach to agriculture, one that includes management for diversity in crop growth habits.
\end{abstract}

\section{INTRODUCTION}

Perennial grain crops have been proposed as a transformative approach to agriculture, to improve food and environmental security (Glover et al., 2010; Jackson, 1980). Grain crops are overwhelmingly annual in growth habit, and replacement with longlived growth types, e.g., perennial analogues, could potentially provide new options for sustainable farming. Perennial crops can provide staple food crops that also achieve resource conservation, save labour and seed, provide weather resilience and potentially, multiple products such as grain plus livestock fodder or fuel wood (Cox et al., 2006). Benefits to wider society are associated with perennial plant types, such as mitigation of greenhouse gases and water quality gains, and these are directly attributable to the unique soil building properties of perennial life forms (Culman

ๆCorresponding author. Email: snapp@msu.edu; Contact address: Department of Plant, Soil and Microbial Sciences, Michigan State University, East Lansing, MI 48824, USA. 
et al., 2013). Once established, perennial crops provide living roots and soil cover that persist over much of the year, which is key to many environmental services (Larkin et al., 2014). However, there are unique risks associated with perennials, such as the potential to act as disease and pest reservoirs, and a growth habit that may constrain yield potential through a slow establishment phase and diversion of resources from reproduction to tissues that ensure survival and regrowth in subsequent years (Jaikumar et al., 2014).

Agronomy has placed front and centre the goal of achieving substantial gains in grain yield, in an annual crop type. There has been limited research by agronomists on achieving multiple products from a field crop, or other growth types, such as biannual or perennial life forms. In the service of this 'annual project', the harvest index of crop varieties has been on a continuous upward trend in recent decades (to as high as 60\%; DeHaan and Van Tassel, 2014). For most perennials, food production is modest to nil, as forage or fuel wood is often the primary production function. Perennials may be promoted in agricultural development projects, but typically as technologies used to improve annual cropping systems over the long-term, enhancing the sustainability of annual food crop production systems. Agroforestry species grown within or near fields of cereal crops are a widely promoted example of perennial diversification (Garrity et al., 2010).

In this review, we explore how agronomists have placed annual grain crop production at the centre of development efforts and question why there has not been a wider lens, one that includes perennial grain crops as an option. Are there good reasons for this narrow focus on annuals, such as poor performance of perennials in producing food and other ecosystem services? Or, is there evidence of farmer practice and interest in perennial forms of field crops, evidence that has been largely ignored? For instance, there is historical evidence of the use of perennial grain crops in Eastern and Southern Africa, including the once-widely grown indigenous pulse crop, lablab (Lablab purpureus), and a perennial form of sorghum (Buchanan, 1885; Moore and Vaughan, 1994). We focus in this paper on two grain crops, sorghum (Sorghum bicolor [L.] Moench) and pigeon pea (Cajanus cajan (L.) Millsp.) that are on occasion grown as perennial ratoons in rain-fed farming systems ${ }^{1}$. Both crops have the genetic potential to ratoon, which involves cutting back the crop after harvest (near the crown or plant base), and carrying out harvests in subsequent years based on plant regrowth. We find evidence that ratoon management of pigeon pea by smallholders in Africa is a widespread practice - for instance, in Malawi (Rogé et al., 2016) - which allows the crop to be grown for two or more years of production. A practice that persists despite an overwhelming focus on annual forms of pigeon pea in agronomic and plant breeding research is somewhat surprising. Sorghum ratooning nowadays appears to be less common, although we found one study that suggests widespread use of this system among smallholder farmers in Ethiopia (Mekbib, 2009).

\footnotetext{
${ }^{1}$ Rice is another cereal that has the potential for ratooning, when grown within irrigated production systems. However, we did not consider irrigated agriculture here as this comprises a small part of Africa's agricultural landscape.
} 
Perennial grain crops constitute an underexplored and contested area of agricultural research. We approach the topic from a multidisciplinary perspective, bridging scholarship in anthropology, geography and agronomy. First, we introduce the concept of perennial grains as a new type of crop species that integrate perennial properties through plant breeding - and the concept of ratooning, an agronomic practice that uses perennial traits in annual crops. Second, we consider the central role of annual, high-harvest index crops in development-oriented agronomy. Third, we reflect on how this annual worldview may have evolved, and consider the role perennials could play in providing alternatives for sustainable intensification (SI). We then present case studies of pigeon pea and sorghum, crops with ratoon potential, grown on smallholder farms in Africa. Finally, we discuss why development-oriented agronomy has rarely considered perennial grains, and if perennial crop options deserve to be explored.

\section{PERENNIAL GRAINS}

What is a perennial grain? Is it similar, or radically different from 'perennializing' through ratooning, as is practiced for crops such as sorghum or pigeon pea? Perennial crops can be achieved through the deliberate incorporation of perennial plant traits into annual crops, and this has been attempted by Russian wheat breeders as far back as the 1930s (Kane et al., 2016). Winter hardiness, tolerance to extreme weather and marginal soils were key goals of early breeding efforts to develop a perennial form of wheat (Vavilov, 1934). And although such efforts have continued in a sporadic manner, few lines with adequate yield potential and strong regrowth have been developed and evaluated in field settings (Cox et al., 2006; Culman et al., 2013; Glover et al., 2010). Novel perennial wheat and rye genotypes for dual use as food and fodder are the one exception (Bell et al., 2008; Jaikumar et al., 2012; Larkin et al., 2014). Recently, research has expanded to explore farmer interest in perennial grains and selection criteria to be used in the development of these novel crops (Adebiyi et al., 2016). Crop simulation models also allow exploration of plant traits in annual crops and perennial analogues, such as high grain yield, and potential trade-offs associated with a large root mass in the latter (Vico and Brunsell, 2018). Much remains to be done before perennial grain varieties are available for widespread testing (Adebiyi et al., 2016; Waldman et al., 2017).

The idea of enhancing and or developing perennial growth in annual cereals and pulses is controversial (DeHaan and Van Tassel, 2014; Glover et al., 2010; Vico and Brunsell, 2018). There are clearly challenges posed by crops that act as disease and pest reservoirs, and in some farming systems, controlled livestock grazing is necessary for the survival of perennial crops (Cox et al., 2006). Opportunity costs associated with the low grain yield relative to the high harvest index of annual crops are one of the most persistent critiques of perennial crops (Smaje, 2015). Agronomic evaluation of perennial analogues of annual wheat and rye suggest a substantial yield penalty. For example, a field study of new perennial wheat lines in Michigan found 20 to $60 \%$ reduction in grain yield, relative to annual varieties (Jaikumar et al., 2012). In 
Australia, large yield penalties have been observed for perennial wheat lines in high yield potential sites (Hayes et al., 2012). This is not surprising as, to date, minimal investments have been made in breeding perennial forms of annual crop species (Glover et al., 2010). Further, wheat derivatives are not reliably perennial as yet, with highly variable regrowth, and grain quality being rarely adequate (Hayes et al., 2012). This comprehensive study in Australia by Hayes and colleagues did however produce evidence that disease resistance to many common wheat pathogens was present in perennial wheat germplasm. Further, eco-physiology experimentation points to a high potential for up-regulation of photosynthesis in perennial genotypes of wheat and rye (Jaikumar et al., 2014). This enhanced photosynthesis ability suggests that perennials may be able to support high grain yields, although substantial research efforts would be required to translate this potential into improved germplasm and viable agronomic systems (DeHaan and Van Tassel, 2014).

Skeptics of perennial grains further raise the point that the domestication of annual grain crops has been highly successful and widespread (Van Tassel et al., 2010). It is possible that during the process of crop domestication, in order to fit annualized migration patterns, annual crop growth patterns were favoured. This historic focus on annual life forms of cereals and pulses is under reconsideration in localized efforts, around the globe. This is evidenced by publications from various locations in North America, Europe, China and Australia (Adebiyi et al., 2016; Bell et al., 2008; Larkin et al., 2014; Zhao et al., 2012).

\section{RATOON MANAGEMENT}

Overall, crop breeding and historic selection processes have favoured annuals, yet there are still vestiges of perennial crop growth habits in annualized crops, as exemplified by ratooned rice, sorghum and pigeon pea (Kane et al., 2016; Van Tassel et al., 2010). These crops have perennial traits, and although widely grown as annuals, they can be grown as ratoon crops (cut back after the first harvest and regrowth of branches or tillering allows production of subsequent harvests). Ratoons are not strong perennials and plants die after two or more harvests, in contrast to the goals stated by perennial grain breeders to produce plants that produce grain reliably over 4 or more years (Cox et al., 2006). Yet, ratoons do have some of the features that are associated with bred perennial grains.

As germplasm with strong perennial features is not yet available for tropical grain crops, ratoons are considered as part of this review. This type of management provides an opportunity to consider the extent to which perennial features are valued, or fit within an African farm context. Over the past three decades, there has been sporadic evidence of ratoon use from African rural surveys (Chauhan et al., 1987; Mekbib, 2009). One report considers ratoon-compatible pigeon pea landrace selection (Gwata and Silim, 2009), and dual-purpose sorghum production of forage and grain through ratoon management has been reported in the Americas and Asia (Rao et al., 2013; Vinutha et al., 2017). Overall, research on ratoon management of grain crops has been modest in scope, as highlighted in a recent bibliographic review (Kane et al., 2016). 
ANNUAL GROPS AND SUSTAINABLE INTENSIFICATION

Agronomists involved in development efforts have taken up the cause of SI pathways for African farmers. The goal is not just to move farmers out of poverty, but also to protect the environment for future posterity. SI technologies include a suite of management approaches for annual crops, from conservation agriculture to organic agriculture (Montpellier Panel, 2013; Petersen and Snapp, 2015). SI technologies generally exhibit high performance on productive soils, where investments have been made to ensure pest regulation and an adequate supply of water and nutrients. However, in poorly resourced African farm environments, many SI technologies are unreliable in performance. This is a growing problem, as smallholder farmers in Africa rely increasingly on marginal lands.

To ensure sustainable production and agricultural performance on marginal lands more generally, attention must be paid to the natural resource base. For the most part, Africa has experienced increases in production by bringing more land under production, rather than by increasing productivity (Fuglie and Rada, 2013). It is not enough to increase farmer access to fertilizers and to annual cereals that respond to fertilizers, such as modern maize varieties. This has been a successful 'green revolution' recipe for the water-endowed productive farm-lands of the US Midwest, Central America and Asia, where short-statured rice, wheat and maize genotypes with a harvest index of $50 \%$ have been developed. Combined with input intensive agronomy, this allows for swift translation of applied nutrients into grain. Further, these varieties include extra early and short-duration growth types that facilitate agricultural intensification through sequencing of double and triple crops per year. An inadvertent consequence of high harvest index crops is the loss of biomass that could be used for other purposes. Indeed, to support SI, biomass has been highlighted as a key resource that is needed for multiple purposes such as soil building and livestock feed (Valbuena et al., 2012). Perennial grain crops present an opportunity to redress the imbalance caused by highly annualized, grain-centric crops, and could be developed either as options to complement annual crops, or as substitutes. This has been called a 'weak' versus 'strong' perennial grain vision, where the latter is represented as promoting a future agricultural landscape dominated by perennial grain crops and other perennials, with few annuals to be seen (Jackson, 1980; Smaje, 2015).

The discussion around a 'weak' versus a 'strong' perennial grain vision may miss the point, as it suggests we need to choose which perennial pathway, whereas all paths to date have been annual ones. Research and extension has almost completely focused on early maturing fast growth traits, combined with allocation of photosynthate and nutrients towards reproductive structures. This has been at the expense of roots, vegetative and supporting tissues. So we currently have a 'strong' annual grain vision, and do not consider perennial grain crops - either strong or weak - as part of the picture. This annual focus may neglect environmental goods and services as well as farmer expressed priorities, at least in some incidences. Indeed, participatory variety selection, where farmer views are the basis for the assessment of suitability, shows 
that attributes associated with community resilience are often preferred along with productivity (Ashby, 2009). We will come back to this topic below, through a case study of pigeon pea.

THE VISION OF 'MODERN' AGRICULTURE: EQUATING CROP IMPROVEMENT WITH AN INCREASED HARVEST INDEX

Let us consider next how an increase in harvest index has come to be associated with crop improvement (Lawn, 1989). The harvest index of grain crops is determined by grain weight as a proportion of the total aboveground plant biomass. Consider, for example, cowpea, a study conducted in Niger in the early 1990s found that local land races generally had a harvest index in the range of $22-40 \%$, whereas modern varieties had a harvest index in the range of 32-50\% (Ntare and Williams, 1992). A recent study in Nigeria found that local cowpea varieties had harvest index values in the range of $14-20 \%$ and improved varieties were in the range of $20-34 \%$ (Kamai et al., 2014). This study also showed that harvest index is related to crop growth duration and determinacy of the variety, with a lower harvest index consistently found in long duration, indeterminate varieties. However, not all modern crop varieties are short duration and have high harvest indices. In cowpea, there are modern dual-purpose varieties with a moderate harvest index that, in addition to grain, produce copious amounts of leaves that can be harvested for human consumption as a vegetable, for livestock fodder or green manure (Kristjanson et al., 2005). Plant breeding efforts that took into account such dual-purpose traits in cowpea led to one of the most successful examples of small-scale farmer adoption in pulse crops (Pachico, 2014).

There are inadvertent disadvantages associated with breeding modern crop varieties that have a high harvest index and a determinant growth pattern. One consequence is that this minimizes the ability of a crop to bounce back from a pest invasion or extreme weather event. Indeterminate crop species can flower again and again after disturbance, providing a form of insurance and resilience to common challenges associated with rain-fed smallholder agriculture. Another biological property that annual crop types sacrifice is that of growth longevity. This markedly constrains the capture of sunlight, limiting the amount of vegetation that can be produced (Glover et al., 2012). There are multiple and competing uses of plant biomass on farms, including livestock feed, as well as fuel wood and soil protection (Baudron et al., 2014; Rogé et al., 2017). A key ingredient for sustainable production is becoming widely recognized: that of root biomass, given that it both directly and indirectly influences soil C sequestration (Kell, 2012; Rasse et al., 2005). Root system architecture and rooting depth are also important determinants of water quality and erosion control. In annuals, root growth is limited by the short duration of growing period, which contributes to shallow penetration of soils. A comparison of a perennial intermediate wheatgrass with wheat, its annual analogue, demonstrated that the perennial grain had root growth that was four-fold higher, and almost no nitrogen loss, under high nitrogen fertilization (Culman et al., 2013). 
Table 1. Challenges and benefits reported to be associated with long-duration varieties and ratoon management of pigeon pea and sorghum on smallholder farms in Africa and India.

\begin{tabular}{|c|c|c|}
\hline & Examples & Reference \\
\hline \multicolumn{3}{|l|}{ Challenge } \\
\hline \multirow[t]{2}{*}{ Reservoir for pests } & Stem borer in sorghum, East Africa & Mohyuddin and Greathead (1970) \\
\hline & $\begin{array}{l}\text { Invasive stem borer species in ratoon } \\
\text { sorghum, S. Africa Pod borer in } \\
\text { ratoon pigeon pea, Nigeria }\end{array}$ & Kfir (1997) \\
\hline Weed control & Grassy weeds in sorghum & $\begin{array}{l}\text { Ajayi et al. (1995), Plucknett et al. } \\
\quad(1970)\end{array}$ \\
\hline Competition with other crops & $\begin{array}{l}\text { Pigeon pea-maize ratoon system in } \\
\text { Malawi }\end{array}$ & Roge et al. (2016) \\
\hline Low ratoon grain yield & Sorghum in India & Willey et al. (1982) \\
\hline \multirow[t]{2}{*}{ Livestock damage } & Pigeonpea in Malawi & Waldman et al. (2017) \\
\hline & Perennial crops & Rogé et al. $(2016,2017)$ \\
\hline \multicolumn{3}{|l|}{ Benefit } \\
\hline \multirow{3}{*}{$\begin{array}{l}\text { Greater yield in ratoon crop } \\
\text { than main crop }\end{array}$} & Sorghum intercrop ratoon in Nigeria & Andrews (1972) \\
\hline & Pigeon pea ratoon, E. Africa & $\begin{array}{l}\text { Rogé et al. (2016), Rusinamhodzi et al. } \\
\text { (2017) }\end{array}$ \\
\hline & Pigeon pea ratoon, Nigeria & Tayo $(1985)$ \\
\hline \multirow{2}{*}{$\begin{array}{l}\text { Low planting costs - less seed } \\
\text { and labour required }\end{array}$} & Sorghum, Kenya & Wilson (2011) \\
\hline & Pigeon pea, Tanzania & Rusinamhodzi et al. (2017) \\
\hline Short growth cycle after ratoon & Sorghum ratoon, India & Willey et al. (1982) \\
\hline Dual use of fodder/grain & Sorghum ratoon, India & Mandal et al. (1965) \\
\hline \multirow[t]{2}{*}{$\begin{array}{l}\text { Soil conservation, water } \\
\text { retention }\end{array}$} & $\begin{array}{l}\text { Sorghum ratoon borders, Mt. Kenya } \\
\text { area }\end{array}$ & Wilson (2011) \\
\hline & $\begin{array}{l}\text { Simulated soil organic matter, } \\
\text { long-duration pigeon pea }\end{array}$ & Smith et al. (2016) \\
\hline Drought tolerance & $\begin{array}{l}\text { Perennial sorghum germplasm } \\
\text { development underway }\end{array}$ & Paterson et al. (2014) \\
\hline Biocontrol of pests & $\begin{array}{l}\text { Stem borer and trap crop of ratoon } \\
\text { sorghum, E. Africa }\end{array}$ & Wilson (2011) \\
\hline Biodiversity & $\begin{array}{l}\text { Sorghum ratoon varieties diverse } \\
\text { germplasm, E. Africa }\end{array}$ & Labeyrie et al. (2016) \\
\hline
\end{tabular}

AN ANNUAL-CENTRIC WORLDVIEW: INADVERTENT GONSEQUENGES

There are challenges associated with perennial life forms, yet at the same time environmental services, forage production and seed-saving benefits have been documented. This is illustrated in Table 1, which presents an overview of literature on ratoon management of pigeon pea and sorghum. The documented benefits raise the question, why have agricultural development efforts to date almost exclusively focused on annual grain production? This could be due to unacceptable risks and challenges associated with ratoons and perennial grains. Or, it could be due to a worldview that focuses tightly on grain yield and increasing the harvest index, as seen in many crop improvement programmes (DeHaan and Van Tassel, 2014; Stamp and Visser, 2012). Similarly, subsidized access to fertilizers and the promotion of cropping systems that transform fertilizer into grain has been widely viewed as successful agricultural 
development, through the 'frame' of grain yield as the key metric (Scoones, 2015). This narrow set of priorities for plant breeding continues with the consolidation of international seed supply chains to the detriment of biodiversity globally (Jacobsen et al., 2015).

However, there may be other factors at play, including a worldview that overlooks the possibility of a perennial grain, or indeed the reality of farmers practicing ratoon management. Commodity agriculture dominates across temperate North America and Europe, where grains are grown in simplified sequences of annual crops, with high reliance on fossil fuels and agrochemical inputs (Jackson et al., 2012). Agronomists and crop scientists who obtain advanced degrees in a landscape of annualized, simplified and highly mechanized agriculture may come to view this as what modern agriculture should look like. This is a productivist view that has roots in Malthusian fears that have been recently revived with the spectre of 9 billion mouths to feed (Tomlinson, 2013).

Authors of this paper have heard high ranking agricultural officers equate sole crops of hybrid, fertilized maize with developed agriculture and mixed cropping systems and ratoons as legacies of the past. Other evidence of this perspective is the imposition in Rwanda of agricultural policies that incentivize sole cropped commodities. The regulations required uprooting of mixed crops, including perennial food crops such as bananas and cassava, and had inadvertent negative impacts on family diets and ecosystem health (Isaacs et al., 2016). In Ethiopia, subsidized fertilizers and a 'green revolution' intensification discourse has promoted broader adoption of annual grain crops, such as maize, and often led to the uprooting of mixed plantings with perennial food crops such as enset (Ensete ventricosum) (Keeley and Scoones, 2000). It is difficult to disentangle how much the disadoption of a perennial staple food crop such as enset is the result of perceptions of what modern agriculture should look like, and how much is driven by the comparative ease of production and economic returns to maize, within a policy framework and development projects that guarantee input and output markets for maize (Scoones, 2015).

Agricultural development visions that rely on large doses of agro-chemicals and overly simplified cropping systems have been critiqued on the basis of environmental sustainability (Childers et al., 2011; Snapp et al., 2010); however, other overlooked and indirect consequences may include reduced livelihood resilience. This has rarely been grappled with in a narrative dominated by commoditization, and policies that focus on sole crops, with limited engagement with farmers' cultural values or concerns about a world experiencing rapid change, imperfect market access, and shocks from extreme weather events (Isaacs et al., 2016). Specific case studies have reported on the role that perennial food crops such as cassava, or enset, play in helping farmers and rural communities cope with a changing climate (Jarvis et al., 2012; Scoones, 2015), but there has been almost no systematic attention to the possible vulnerabilities of a focus on intensification of annual grain crop production. Is this a failure of imagination, or due to intrinsic biological problems associated with perennial grain crops?

Alternative visions on how to feed the world's growing human population have been articulated, despite the productivist and Neo-Malthusian narrative that often 
dominates discussions on plant breeding. Alternatives often encompass how to increase the productivity of marginal agricultural spaces, adoption of an evolutionary and ecosystem perspective and increasing people's access to food and robust germplasm. Calls to establish institutes dedicated to the breeding of perennial food crops for marginal agricultural environments date back to Smith's (1929) book Tree Crops: A Permanent Agriculture. An evolutionary plant breeding perspective builds on diverse land race populations that are better attuned to local needs and that exhibit greater stability in times of disturbance than conventionally bred crops (Ceccarelli, 2014; Johnson and Goldstein, 2015). This type of outcome is best achieved through ongoing and empowering relationships between plant breeders and farmers to better meet local needs and to promote the exchange of knowledge (Jones et al., 2014). With this in mind, the next section considers efforts to perennialize agricultural development to date.

PERENNIALIZATION FOR A SUSTAINABLE FUTURE IN AGRIGULTURE

Cover crops, green manure and agroforestry systems are all approaches that have been promoted as means to address SI in Africa (Petersen and Snapp, 2015). However, these soil-rehabilitating and sustainability-enhancing technologies are generally associated with high opportunity costs for land or labour or both. A large body of research has attempted to integrate soil-rehabilitation species with crop production in a manner that maximizes crop production, while minimizing labour requirements. Diversification with legume crops is one way to enhance biological nitrogen fixation and nutrient recycling, while at the same time produce agricultural products, and thus mitigate potential opportunity costs associated with alternative management. However, annual, short-statured legumes have become common, due to crop improvement efforts described earlier, and an inadvertent consequence is removal of large amounts of nutrients at crop harvest (Giller and Cadisch, 1995). Further, a highly annualized legume precludes accessory products such as vegetable use of leaves, fodder, fuel wood, biological nitrogen fixation or soil conservation services.

Traditional pigeon pea cropping systems provide a counter example to highly annualized legume crops (Peter et al., 2017; Rusinamhodzi et al., 2017). Diversification with this crop addresses the need for soil conservation and fuel wood, while simultaneously providing a grain crop, particularly when grown using local practices such as mixed cropping and ratoon management that produced two crops and large amounts of vegetative material (Orr et al., 2015; Waldman et al., 2017). Lablab is another crop species that can be grown as a short-lived perennial, through ratoon management. This minor crop produces grain, edible leaves, and livestock feed. It was once widespread in Africa (Kimani et al., 2012). The growth duration is determined by the environment as well as genetics, as both pigeon pea and lablab have highly plastic responses to day length and temperature as well as rainfall patterns. Generally, growth duration of both is more than six months, and they can be ratooned once or twice to provide 2 or more years of sunlight capture and regeneration of soil nitrogen and phosphorus, along with bioenergy, fodder and food (Snapp et al., 2010). 


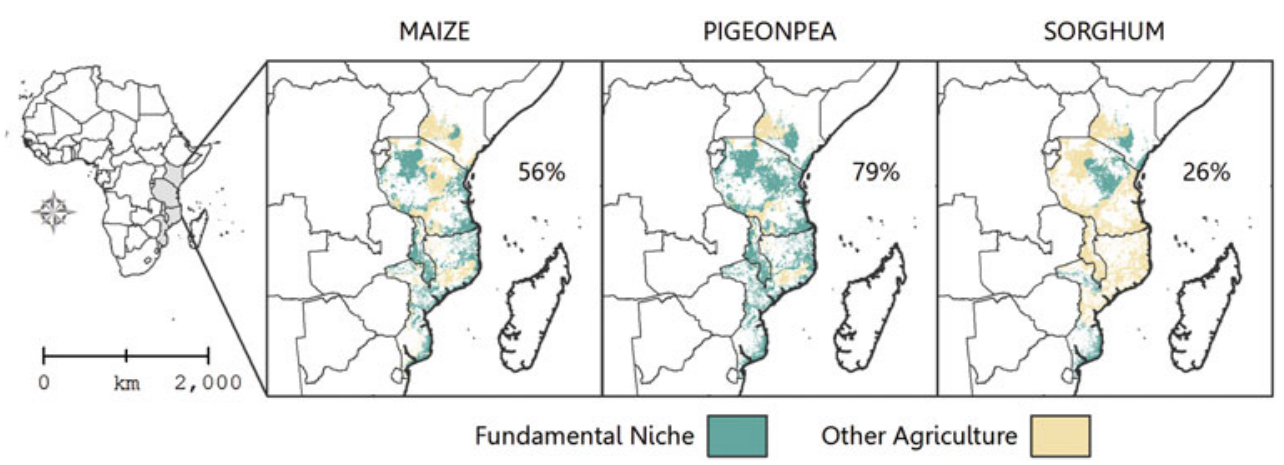

Figure 1. Climate niche maps for maize, pigeon pea and sorghum for Southeast Africa (Kenya, Tanzania, Malawi and Mozambique) based on temperature and precipitation. Temperature and precipitation parameters used for maize*: $23.8-32.2^{\circ} \mathrm{C}$ and $750-1217 \mathrm{~mm}$, respectively. Temperature and precipitation parameters used for pigeon pea**: $22.7-30.9^{\circ} \mathrm{C}$ and $544-1263 \mathrm{~mm}$, respectively. Temperature and precipitation parameters used for sorghum*: 22.1-33. ${ }^{\circ} \mathrm{C}$ and $317-833 \mathrm{~mm}$, respectively. Percentages represent the fundamental niche proportion of agriculture. Temperature data collected from NASA Moderate Resolution Imaging Spectroradiometer (MODIS, MYD1 1B3.006) (NASA LP DAAC, 2015). Precipitation data collected from NASA/JAXA Tropical Rainfall Measuring Mission (TRMM-3B43) (NASA/JAXA TRMM, 2016). Data are annual averaged values between 2003 and 2014. Fritz et al. (2015) global cropland percentage map used to delineate areas by agriculture. Parameter sources: *FAO (2005), Pingali (2001), Sánchez et al. (2014), Wood and Moriniere (2013); **Carberry et al. (2001), FAO (2005), Kimani (2000), Omanga et al. (1995), Sardana et al. (2010), Silim and Omanga (2001), Valenzuela and Smith (2002); ***Chipanshi et al. (2003), FAO (2005), Mishra et al. (2008), Wood and Moriniere (2013).

Alternative agricultural practices rely on crop diversification in a broader manner than legumes alone, including growing multiple plant life forms to provide resilience and buffer against risk (Jackson et al., 2012; Jacobsen et al., 2015). Perennial germplasm for fodder and biofuel production is widely considered as an integral component of SI, yet perennial grain crops have only occasionally been considered. Below, we reflect on two grain crops - pigeon pea and sorghum - that have perennial properties that could be exploited to develop perennial production systems. To this day, they are grown as semi-perennials through ratoon management in some parts of Africa. Thus, they provide examples of existing staple grain crops that have both annual and perennial features. We discuss their current role in African smallholder farming systems, and agronomic and plant breeder efforts to improve them. We explore the extent to which crop science research priorities have - and have not coincided with farmer priorities for utilization of pigeon pea and sorghum. Finally, we consider the potential contributions, and drawbacks, associated with promotion of perennial properties of pigeon pea and sorghum in Africa.

\section{PIGEON PEA}

Approximately, $79 \%$ of agricultural land across Southern and East Africa is suitable for pigeon pea cultivation (Figure 1), although current production is primarily concentrated in Southern Malawi and North-Central Tanzania (Figure 2). This concurs with earlier findings that the agro-ecosystem niche for pigeon pea is much larger than that for maize, the most widespread crop (Peter et al., 2017). There is a 


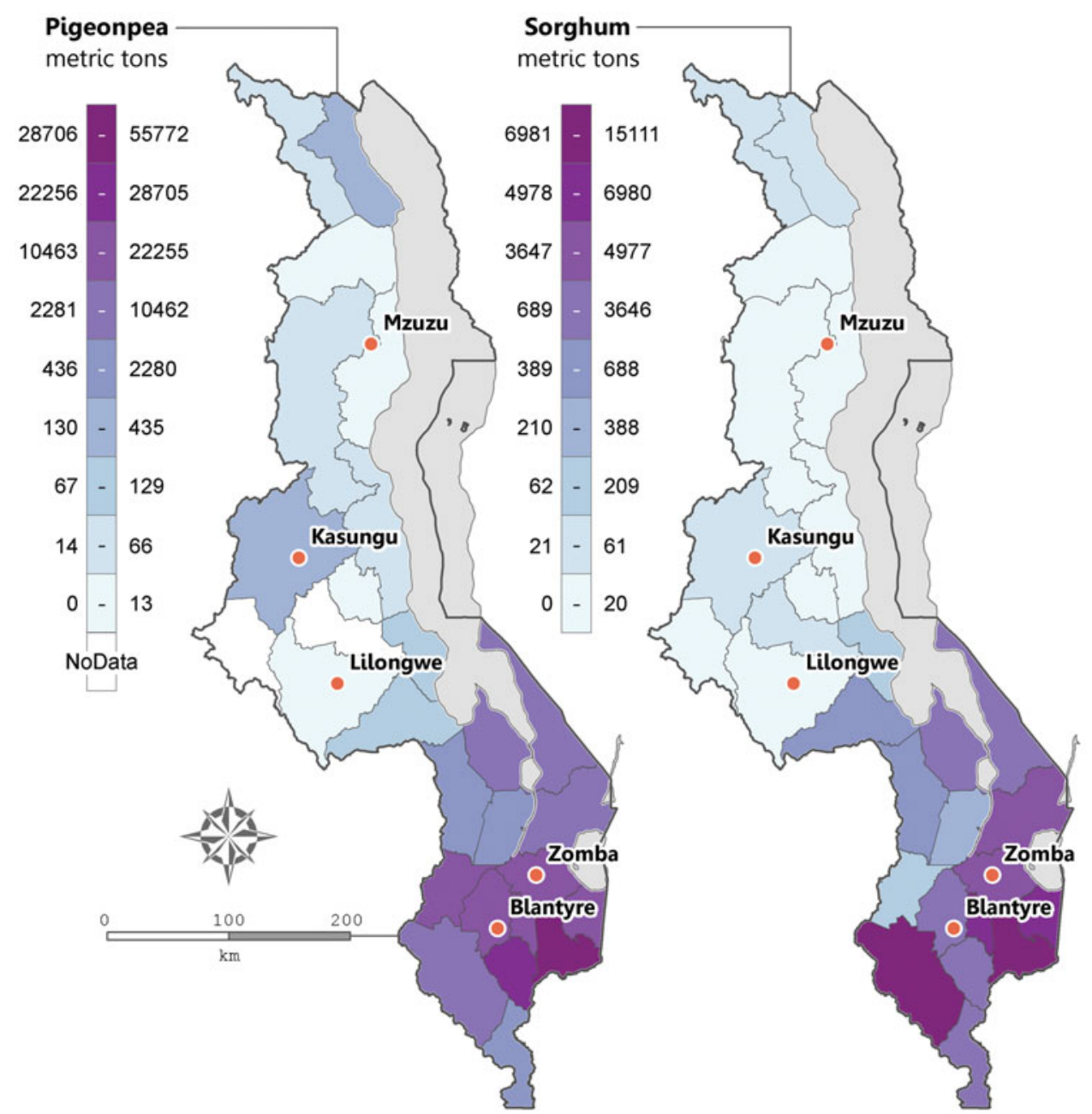

Figure 2. Pigeon pea and sorghum production by district in Malawi for 2012. Source: Agricultural Production Estimates Survey (APES), Malawi Ministry of Agriculture and Food Security (MoAFS 2012).

gap between the biophysical conditions conducive to growing the crop and where it is actually grown, due to the market context and complex cultural and socio-economic factors that govern why farmers grow pigeon pea. Table 1 presents findings from the literature on a wide range of farmer reported benefits, as well as challenges, that were associated with growing traditional varieties (long-duration types) and ratoon management. Local context matters, as found in a semi-qualitative survey conducted in Malawi where ratoon management of pigeon pea was reported in North and Central Malawi, but rarely in the South (Roge et al., 2016). This may be related to the prioritization of grain production by farmers in the South, whereas conservation and soil fertility purposes were frequently reported as reasons for growing pigeon pea elsewhere (Figure 3). The latter are environmental benefits, which are expected to be 
Table 2. Pigeon pea uses, desirable attributes and management practices from the perspective of farmers and researchers as documented in the literature.

\begin{tabular}{|c|c|c|}
\hline & Attributes & Source \\
\hline \multicolumn{3}{|l|}{ Farmer priorities } \\
\hline Dual purpose, soil fertility and food & Indeterminate, long duration & Snapp et al. (2002) \\
\hline Dual purpose, income and food & $\begin{array}{l}\text { Indeterminate and ratoon } \\
\text { management }\end{array}$ & Ortega et al. (2016), Rogé et al. (2016) \\
\hline Food & $\begin{array}{l}\text { Insect tolerance, intercrop ability, } \\
\text { grain yield }\end{array}$ & $\begin{array}{l}\text { Simtowe et al. (2010), Snapp and } \\
\quad \text { Silim (2002) }\end{array}$ \\
\hline Dual purpose, Fuel wood and food & $\begin{array}{l}\text { Grain yield, medium duration, thick } \\
\text { stems and leafy }\end{array}$ & Orr et al. (2015) \\
\hline \multicolumn{3}{|l|}{ Research priorities } \\
\hline Income & Seed colour and size (white, bold) & Simtowe et al. (2010) \\
\hline Income & Earliness, grain yield & Orr et al. (2015) \\
\hline Income & $\begin{array}{l}\text { Earliness, erect architecture and } \\
\text { determinant reproduction, hybrid }\end{array}$ & $\begin{array}{l}\text { ICRISAT 'Happenings' (December, } \\
\text { 2015) }\end{array}$ \\
\hline Food income & $\begin{array}{l}\text { Earliness, erect architecture, } \\
\text { determinant reproduction }\end{array}$ & Lawn (1989) \\
\hline Food income & $\begin{array}{l}\text { Early, high yielding varieties, high } \\
\text { plant population density }\end{array}$ & Malawi Guide to Agriculture (2010) \\
\hline
\end{tabular}

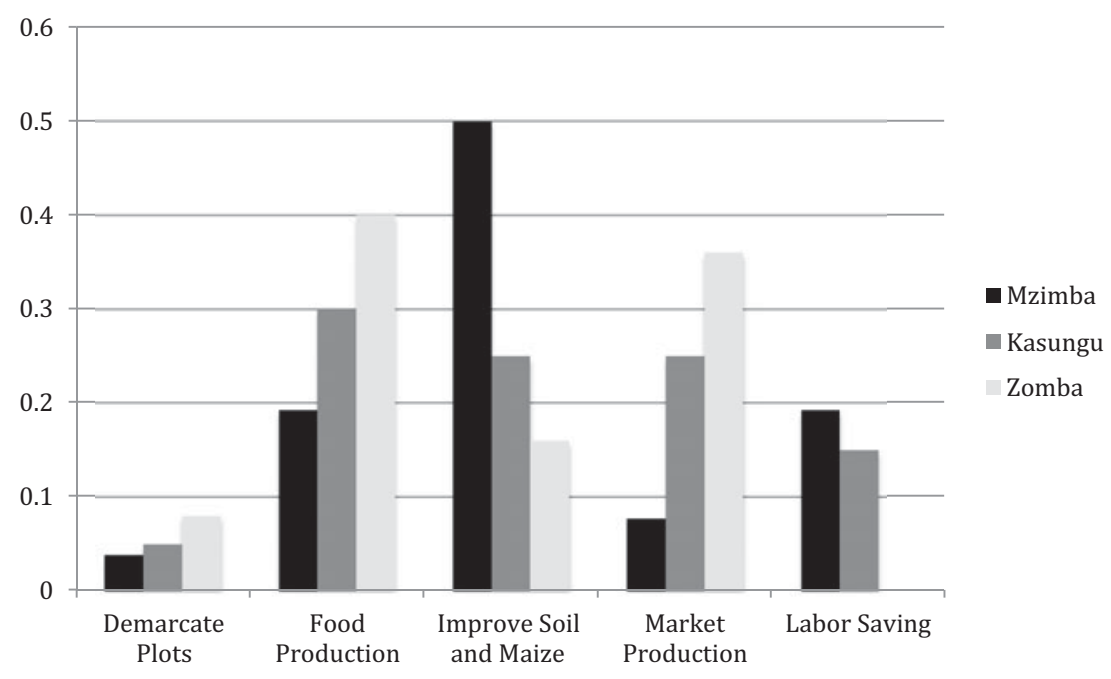

Figure 3. Primary reason given for growing pigeon pea based on 48 farmer interviews conducted in three districts in Malawi, Mzimba (Northern), Kasungu (Central) and Zomba (Southern), adapted from Rogé et al. (2016).

high under ratoon management due to the large root systems associated with a long growth cycle (Kell, 2012).

In some cases, there is an apparent mismatch between researcher priorities for pigeon pea, and farmer interests. As shown in Table 2, surveys have documented localized farmer preferences that include multi-use features of pigeon pea (i.e., forage, fuel wood and food production), and indeterminate, long-lived varieties, some of 
which are grown under ratoon management. A 'choice experiment' carried out with Malawian farmers involved presenting information on a hypothetical perennial pigeon pea (Waldman et al., 2017). Interest was highly localized, with some farmers choosing scenarios where a perennial pigeon pea grown as a maize intercrop was associated with a short-term loss in maize yield along with long-term soil productivity gains, whereas other farmers were not willing to accept any short-term losses. Another study in Malawi found that about $40 \%$ of interviewed farmers managed pigeon pea as a ratoon crop, over 2 or 3 years (Rogé et al., 2016). A survey in Tanzania documented a range of pigeon pea management practices, including widespread use of ratoon (Rusinamhodzi et al., 2017). Evidence of farmer interest in multiple services from pigeon pea is the rapid spread from Mozambique to Southern Malawi of a new genotype of pigeon pea with a thick stem, providing a source of fuel wood on top of food, income and soil fertility (Orr et al., 2015). At the same time, Orr and colleagues found that farmers remain primarily interested in food production associated with this novel pigeon pea, and secondarily were interested in income and/or fuel wood. This highlights the importance of dual and triple uses as motivation for growing this crop (Figure 3).

Overall, the evidence is fragmentary, but it does appear that some East African farmers value longer duration pigeon pea and ratooning. At the same time, researcher priorities have almost universally emphasized short-stature, annual forms of pigeon pea (Table 2). This focus may be influenced by priorities of the India based International Crops Research Institute for the Semi-Arid Tropics, which has the world's largest gene bank for pigeon pea and has invested heavily in the development of extra early short-duration varieties with an erect architecture, a high harvest index, and market-preferred grain quality traits, which fit specific Indian cropping system contexts. At the same time, little attention has been paid to producing stems for fuel wood or foliage for other purposes, which are likely important within African contexts (ICRISAT Happenings, 2015; Table 2). Indeed, few plant improvement efforts have considered land races of pigeon pea that include a huge diversity in duration, determinacy. Nor has the ratoon ability of pigeon pea been systematically evaluated by scientists (Gwata and Silim, 2009).

It is important to note here that perennial growth types have both advantages and disadvantages. As shown in Table 1, these include on the one hand reduced costs associated with seed and labour savings, and extra services (e.g., soil conservation, forage and fuel wood), and on the other hand, challenges such as risk of pest infestation due to extended presence of the crop host (Daniel and Ong, 1990). Not surprisingly, farmer interest varies, and indeed a range of varieties and growth habits are grown. Medium-duration varieties have been released recently in Malawi and Tanzania, and these have been taken up in some locations, along with traditional, long-duration germplasm (Myaka et al., 2006; Simtowe et al., 2010).

One research gap is the time-frame and extent of soil improvement to be expected from perennial forms of pigeon pea management, in terms of soil organic matter accrual. Pigeon pea reliably enhances soil nitrogen status and maize yield in rotational and intercrop systems (Myaka et al., 2006; Rusinamhodzi et al., 2017). However, on- 
farm research has rarely detected gains in soil organic $\mathrm{C}$ from pigeon pea-based technologies (Snapp et al., 2010). Simulation modelling results are consistent with the potential of pigeon pea to support appreciable soil C gains in degraded soils in Central Malawi (Smith et al., 2016). Soil organic matter starting conditions and environment conditions matter, but for marginal sites in Central Malawi, a 25-year simulation with the model APSIM demonstrated soil $\mathrm{C}$ and $\mathrm{N}$ gains of $15-30 \%$ associated with pigeon pea mixed cropping, relative to sole maize. There are considerable challenges to detect soil $\mathrm{C}$ and $\mathrm{N}$ accrual in field experimentation, these include the long-time horizon involved in $\mathrm{C}$ sequestration processes, and the highly variable nature of soil $\mathrm{C}$ on smallholder fields. Legume shrub-maize intercrops have been shown to be associated with soil C gains in Southern Malawi on an agroforestry research site maintained for more than 15 years (Beedy et al., 2010). This indicates the value of long-term monitoring and longitudinal studies.

Crop damage by livestock in the dry season is a significant barrier to growing a long-duration pigeon pea or a ratoon crop in many locations (Snapp and Silim, 2002; Waldman et al., 2017). This is less of an issue in the Southern Region of Malawi, perhaps related to the small landholdings and the existence of markets for pigeon pea, where community norms are in place that control livestock so as to protect perennial, ratooned pigeon pea (Orr et al., 2015; Ortega et al., 2016).

Pigeon pea research and extension recommendations in Malawi focus almost exclusively on short-duration, large-seeded and modern varieties. Although the practice is widespread, there are no recommendations for ratoon management in the Malawi Guide to Agriculture (2010). Our literature review found an overwhelming focus on annual production of short and medium-duration types of pigeon pea, with few reports on land races, and almost no attention to ratoon traits (Table 2). Interestingly, Gwata and Silim (2009) reported on a study of long-duration land races, and then Gwata published an article advocating for short-duration types of pigeon pea for smallholder farmers, despite having documented the predominance of medium- and long-duration types among pigeon pea growers across East Africa, and the widespread use of ratoons (Gwata and Mzezewa, 2013).

There is evidence of growing interest in pigeon pea as an economic diversification crop in Southern and East Africa (Simtowe et al., 2010). This, combined with the success of a farmer selected of dual purpose pigeon pea (for grain and fuel wood), indicates that there may be unmet demand for multipurpose types of pigeon pea (Orr et al., 2015). Efforts to develop and promote access to perennial forms of pigeon pea, as well as extension messages about ratoon management, all have been notably lacking to date. Thus, we have limited knowledge of the extent and scope of demand for perennial growth habit types, along with other diverse pigeon pea germplasm.

\section{SORGHUM}

The ecological niche suitable for growing sorghum is largely confined to the arid to semi-arid zones with low rainfall and high evapotranspiration (Figure 1). This includes a swath across West Africa from Chad to Senegal, and another swath from 
Table 3. Sorghum uses, desirable attributes and management practices from the perspective of farmers and researchers as documented in the literature.

\begin{tabular}{|c|c|c|}
\hline & Attributes & Source \\
\hline \multicolumn{3}{|l|}{ Farmer priorities } \\
\hline Food & Yield, grain quality traits, striga resistance & Gebretsadik et al. (2014) \\
\hline Food, quality & Taste, grain yield, bird and post-harvest pest resistance & Mofokeng et al. (2016) \\
\hline Dual purpose & Forage (quantity and quality, sweetness), fuel wood and grain & Mekbib (2009) \\
\hline Food, biomass & Yield, grain quality traits, striga resistance, dual use & $\begin{array}{l}\text { Adesina and Baidu-Forson } \\
\quad(1995)\end{array}$ \\
\hline \multicolumn{3}{|l|}{ Researcher priorities } \\
\hline Early maturity & Drought tolerance through early maturity & $\begin{array}{l}\text { Adesina and Baidu-Forson } \\
\quad(1995)\end{array}$ \\
\hline Food, climate resilient & Insect pest and fungal resistance, drought tolerance & Morris et al. (2013) \\
\hline Dual purpose & Forage and food & Kante et al. (2017) \\
\hline Early maturity & Hybrids for yield, early maturity & Reddy et al. (2006) \\
\hline
\end{tabular}

the horn of Africa through South Africa, including about one-quarter of arable land in East and Southern Africa. Sorghum production is shown for Malawi and Tanzania, where it is often associated with biophysically marginal areas, including low rainfall and degraded, infertile or saline soils (Figure 2).

Throughout Africa, smallholder farmers grow sorghum landraces, which are generally tall statured and long duration. Farmer preferences for sorghum germplasm are presented in Table 3, and the contrast with researcher priorities mirrors many of the issues described for pigeon pea. From North to East Africa, and across West Africa, farmers overwhelmingly prefer local sorghum germplasm with traits such as grain quality, tall-stature and high stover to grain ratios for multiple farm uses (e.g., feed, fuel wood and construction) (Kimber et al., 2013; Rogé et al., 2017). In Ethiopia, for example, fodder quantity and quality (sweetness) were important adoption criteria and only a small proportion of farmers were interested in planting modern varieties (Gebretsadik et al., 2014; McGuire, 2002). An exception is Southern Africa where modern varieties account for about one-quarter of sorghum production (Alumira and Rusike, 2005). This includes adoption of short-statured, high harvest index types with early maturity. In the near future farmer adoption of modern varieties may pick up in West Africa as breeding efforts have started to take into account local preferences for tall-statured, long-duration varieties of Guinea-Race sorghum. Indeed, there are promising signs of farmer interest in improved sorghum varieties that are suited to dual-purpose use (Kante et al., 2017). This stands in contrast to earlier sorghum research priorities that did not always correspond with farmer priorities (Table 3).

Sorghum is the most extensively grown cereal on smallholder farms throughout much of West Africa, and it is highly suited to the dominant environmental conditions of variable rainfall, aridity and infertile soils. Ratoons or perennial forms of sorghum are not grown in the region to any extent that we could ascertain from the literature, with the exception of one publication on Nigeria (Andrews, 1972). However, a recent survey in Mali documented some farmer interest in novel forms of sorghum with perennial properties, this interest was localized and often expressed by women (Rogé 
et al., 2017). Interestingly, in West Africa, farmers have historically relied upon a perennial grain complex, the kreb or kasha grasslands (Harlan, 1989). This grain complex is still harvested to some extent, although it is primarily relegated to marginal lands such as saline or degraded soils from Bornu, Nigeria to Darfar, Sudan.

In contrast to pigeon pea, agronomic research has been conducted on how to improve sorghum ratoon systems. However, investigations have been largely based in Asia or the Americas, with a focus on biofuel or forage production (Rao et al., 2013; Vinutha et al., 2017). Sorghum is a crop that originated in Africa, so it was somewhat surprising to find very few studies on sorghum ratoons based in Africa (Kane et al., 2016). Exceptions include surveys that mention sorghum ratoons as part of complex cropping systems in Nigeria and in Ethiopia (Andrews, 1972; Kfir, 1997; Mekbib, 2009). Ratoon sorghum may have been a widespread historical practice, as it was reported to be used decades past in Zambia, and it was an important coping mechanism in drought years in the 1940s in Malawi (Vaughan, 1987, page 75). This source indicates that ratooning of sorghum was made illegal in Malawi due to concerns about ratoon crops providing a reservoir for disease. This has been a concern expressed frequently in the perennial grain literature (Table 2).

The potential benefits and challenges associated with ratoon sorghum systems are mostly similar to those associated with ratoon pigeon pea (Table 1). In one documented case from South Africa, a new invasive species of stem borer was able to outcompete another species, facilitated by early establishment on ratooned sorghum (Kfir, 1997). One aspect where sorghum apparently differed from pigeon pea was concerns regarding low yields, as a ratoon sorghum crop rarely produces as much, and often 50\% less than the first crop - although not in all cases (Table 1). In contrast, ratoon pigeon pea yields are often higher than the first crop. This is presumably due to differences in growth habit (a grass versus a shrub species).

A recent development in sorghum genetic studies and plant breeding is the exploration of perennial sorghum germplasm as a source of drought tolerance, disease resistance and as a new form of grain crop to provide multiple harvests for smallholders on marginal lands in Africa (Paterson et al., 2014). True perennial forms of sorghum germplasm were planted on Malian agricultural research stations in 2014 (P. Hayford and E. Weltzien, personal communication). Observations are preliminary as yet, but suggest there is interest among some sorghum plant breeders and agronomists in exploring perennial grain possibilities.

Overall, there are expected trade-offs with managing sorghum or pigeon pea as a perennial. Site-specific analysis could help determine under what circumstances and environmental conditions perennial grain crops are expected to provide valuable ecosystem services in support of sustainable production, and where the risks are too high (Peter et al., 2017).

CONCLUSIONS

Perennial grain crops have been an overlooked option in agronomic research for development. This is perhaps a surprising finding, given evidence that some African 
farmers persist in ratooning pigeon pea and sorghum. This observation is made in a context where there is a complete absence of agronomic advice or genetic options tailored towards perennial management. Agronomists have focused almost entirely on grain yields, primarily through intensification of crop production of highly annual crops. This is consistent with a vision of modern agriculture where perennial crops are considered only as candidates for field borders in the service of environmental benefits, and the main field cropping area is dedicated to producing grain (Jackson et al., 2012). In the service of this annual agronomy project, the harvest index of modern crop varieties has been on a continuous upward trend. We raise the question, has this been at the expense of environmental services, resilience, labour-saving or seedsaving benefits? Or is a focus on short-duration crops a necessary one, given that long duration and perennial traits are often associated with less than maximum crop yield.

Agriculture has a colossal footprint, straining the sustainable use of resources and the world's biodiversity. This underlines the need to pay attention to agricultural management that produces ecological services in combination with production. Perennial management of staple food crops offers one way to do this. We suggest that farmers have been pursuing perennial options for years in various corners of the world, including growing mixtures of species with contrasting life-forms, and management through ratoons. Perennial options could open new doors, through the development of long-duration and perennial forms of crops in conjunction with adaptive management. At the same time, we recognize that there are potentially serious risks associated with growing a crop year round, including providing habitat for pests and the opportunity costs associated with modest grain yield levels. Crop scientists could address these challenges. We suggest that agronomists broaden their view beyond an annual-centric one, and consider investing in the perennial grain pipedream.

Acknowledgements. We extend our thanks to the farmers who graciously attended to interviews about perennial crops, and to the Bill and Melinda Gates Foundation who supported this research under Grant OPP1076311. We also appreciate funding from the Global Center for Food Systems Innovation, supported by USAID. Malawi seed systems activities have been supported by Irish Aid and USAID to ICRISAT which are making a difference through increasing access to pigeon pea varieties. No financial interest or benefit has arisen from the direct applications of this research.

\section{REFERENGES}

Adebiyi, J. A., Olabisi, L. S. and Snapp, S. S. (2016). Understanding perennial wheat adoption as a transformative technology: Evidence from the literature and farmers. Renewable Agriculture and Food Systems 31:101-110. doi:10.1017/S1742170515000150.

Adesina, A. A. and Baidu-Forson, J. (1995). Farmers' perceptions and adoption of new agricultural technology: Evidence from analysis in Burkina Faso and Guinea, West Africa. Agricultural Economics 13:1-9.

Ajayi, O., Ezueh, M. I., Tabo, R., Asiegbu, J. E. and Singh, L. (1995). Observations on insect damage to pigeon pea in Nigeria. International Chickpea Newsletter 2:76-78.

Alumira, J. D. and Rusike, J. (2005). The green revolution in Zimbabwe. Electronic Fournal of Agricultural and Development Economics 2:50-66.

Andrews, D. J. (1972). Intercropping with sorghum in Nigeria. Experimental Agriculture 8:139-150. 
Ashby, J. A. (2009). The impact of participatory plant breeding. In Plant Breeding and Farmer Participation, 650-671 (Eds S. Ceccarelli, E. P. Guimarães and E. Weltzien). Rome, Italy: Food and Agriculture Organization.

Baudron, F., Jaleta, M., Okitoi, O. and Tegegn, A. (2014). Conservation agriculture in African mixed crop livestock systems: Expanding the niche. Agriculture, Ecosystems E Environment 187:171-182.

Beedy, T. L., Snapp, S. S., Akinnifesi, F.K. and Sileshi, G.W. (2010). Long-term impact of Gliricidia sepium intercropping and inorganic fertilizer on soil organic matter fractions in maize-based cropping systems. Agriculture Ecosystems \& Environment 138:139-146.

Bell, L. W., Byrne (nee Flugge), F., Ewing, M. A. and Wade, L. J. (2008). A preliminary whole-farm economic analysis of perennial wheat in an Australian dryland farming system. Agricultural Systems 96:166-174. doi:10.1016/j.agsy.2007.07.007.

Buchanan, J. (1885). The Shirè Highlands (East Central Africa) as Colony and Mission ( Eds J. Rankin). London: W. Blackwood; Sons.

Carberry, P. S., Ranganathan, R., Reddy, L. J., Chauhan, Y. S. and Robertson, M. J. (2001). Predicting growth and development of pigeon pea: Flowering response to photoperiod. Field Crops Research 69:151-162.

Ceccarelli, S. (2014). GM crops, organic agriculture and breeding for sustainability. Sustainability 6:4273-4286. doi: $10.3390 /$ su6074273.

Chauhan, Y. S., Venkatratnam, N. and Sheldrake, A. R. (1987). Factors affecting growth and yield short-duration pigeon pea and potential for multiple harvests. Fournal of Agricultural Science 109:519-529.

Childers, D. L., Corman, J., Edwards, M. and Elser, J. J. (2011). Sustainability challenges of phosphorus and food: Solutions from closing the human phosphorus cycle. BioScience 61:117-124.

Chipanshi, A. C., Chanda, R. and Totolo, O. (2003). Vulnerability assessment of the maize and sorghum crops to climate change in Botswana. Climatic Change 61:339-360.

Cox, T. S., Glover, J. D., Van Tassel, D. L., Cox, C. M. and DeHaan, L. R. (2006). Prospects for developing perennial grain crops. BioScience 56:649-659.

Culman, S. W., Snapp, S. S., Ollenburger, M., Basso, B. and DeHaan, L. R. (2013). Soil and water quality rapidly responds to the perennial grain Kernza wheatgrass. Agronomy fournal 105:735-744.

DeHaan, L. R. and Van Tassel, D. L. (2014). Useful insights from evolutionary biology for developing perennial grain crops 1. American Fournal of Botany 101(10):1801-1819.

Daniel, J. N. and Ong, C. K. (1990). Perennial pigeon pea: A multi-purpose species for agroforestry systems. Agroforestry Systems 10:113-129.

Food and Agriculture Organization of the United Nations (FAO). (2005). A (no date available). Zea mays L., Sorghum bicolor (L.) Moench., Pigeon pea Cajanus cajan (L.) Millsp Grassland species profiles. http://agris.fao.org/ agris-search/search.do? recordID=XF2006425545 (last accessed 31 January 2018).

Fritz, S., See, L., McCallum, I., You, L., Bun, A., Moltchanova, E., Duerauer, M., Albrecht, F., Schill, C., Perger, C. and Havlik, P. (2015). Mapping global cropland and field size. Global Change Biology 21(5):1980-1992.

Fuglie, K. O. and Rada, N. E. (2013). Resources, policies, and agricultural productivity in Sub-Saharan Africa. ERR145, U.S. Department of Agriculture, Economic Research Service, February 2013.

Garrity, D. P., Akinnifesi, F. K., Ajayi, O. C., Weldesemayat, S. G., Mowo, J. G., Kalinganire, A., Larwanou, M. and Bayala, J. (2010). Evergreen agriculture: A robust approach to sustainable food security in Africa. Food Security 2:197-214.

Gebretsadik, R., Shimelis, H., Laing, M. D., Tongoona, P. and Mandefro, N. (2014). A diagnostic appraisal of the sorghum farming system and breeding priorities in Striga infested agro-ecologies of Ethiopia. Agricultural Systems 123:54-61.

Giller, K. E. and Cadisch, G. (1995). Future benefits from biological nitrogen fixation: An ecological approach to agriculture. Plant and Soil 174:255-277.

Glover, J. D., Reganold, J. P., Bell, L. W., Borevitz, J., Brummer, E. C., Buckler, E. S., Cox, C. M., Cox, T. S., Crews, T. E., Culman, S. W., DeHaan, L. R., Eriksson, D., Gill, B. S., Holland, J., Hu, F., Hulke, B. S., Ibrahim, A. M. H., Jackson, W., Jones, S. S., Murray, S. C., Paterson, A. H., Ploschuk, E., Sacks, E. J., Snapp, S., Tao, D., Van Tassel, D. L., Wade, L. J., Wyse, D. L. and Xu, Y. (2010). Increased food and ecosystem security via perennial grains. Science 328:1638-1639.

Glover, J. D., Reganold, J. P. and Cox, C. M. (2012). Agriculture: Plant perennials to save Africa's soils. Nature 489:359-361. doi:10.1038/489359a.

Gwata, E. T. and Mzezewa, J. (2013). Optional crop technologies at a semi-arid ecotope in Southern Africa. Fournal of Food, Agriculture and Environment 11:291-295. 
Gwata, E. T. and Silim, S.N. (2009). Utilization of landraces for the genetic enhancement of pigeonpea in Eastern and Southern Africa. Fournal of Food, Agriculture and Environment 7:803-806.

Harlan, J. R. (1989). Wild grass seed harvesting in the Sahara and Sub-Sahara of Africa. In Foraging and Farming: The Evolution of Plant Exploitation, 79-98 (Eds D. R. Harris and G. C. Hillman). London, Boston: Unwin Hyman.

Hayes, R. G., Newell, M. T., DeHann, L. R., Murphy, K. M., Crane, S., Norton, M. R., Wade, L. J., Newberry, M., Fahim, M., Jones, S. S., Cox, T. S. and Larkin, P. J. (2012). Perennial cereal crops: An initial evaluation of wheat derivatives. Field Crops Research. 133:68-89.

ICRISAT Happenings, No. 1704, (2015). An exercise in demand-driven research, a newsletter report on pigeon pea breeders consultation. Infonet biovision. Maize. 2016. http://www.infonet-biovision.org/PlantHealth/Crops/ Maize. ( last accessed 12 September 2016).

Isaacs, K., Snapp, S. S., Chung, K. and Waldman, K. (2016). Assessing the value of diverse cropping systems under a new agricultural policy environment in Rwanda. Food Security 8:491-506. doi:10.1007/s12571-016-0582-x.

Jackson, L. E., Pulleman, M. M., Brussaard, L., Bawa, K. S., Brown, G. G., Cardoso, I. M., De Ruiter, P. G., GarcíaBarrios, L., Hollander, A. D., Lavelle, P. and Ouédraogo, E. (2012). Social-ecological and regional adaptation of agrobiodiversity management across a global set of research regions. Global Environmental Change 22:623-639.

Jackson, W. (1980). New Roots for Agriculture. San Francisco: Friends of the Earth.

Jacobsen, S., Sørensen, M., Pedersen, S. M. and Weiner, J. (2015). Using our agrobiodiversity: Plant-based solutions to feed the world. Agronomy for Sustainable Development 35:1217-1235. doi:10.1007/s13593-015-0325-y.

Jaikumar, N. S., Snapp, S. S., Flore, J. A. and Loescher, W. (2014). Source versus sink regulation of photosynthesis in annual rye, perennial wheat and perennial rye subjected to modest source/sink ratio changes. Crop Science 54:274283.

Jaikumar, N. S., Snapp, S. S., Murphy, K. and Jones, S. S. (2012). Agronomic assessment of perennial wheat and perennial rye as cereal crops. Agronomy fournal 104:1716-1726. https://org/10.2134/agronj2012.0291.

Jarvis, A., Ramirez-Villegas, J., Campo, B. V. H. and Navarro-Racines, C. (2012). Is cassava the answer to African climate change adaptation?. Tropical Plant Biology 5:9-29.

Johnson, E. R. and Goldstein, J. (2015). Biomimetic futures: Life, death, and the enclosure of a more-than-human intellect. Annals of the Association of American Geographers 105:387-396. doi:10.1080/00045608.2014.985625.

Jones, K., Glenna, L. L. and Weltzien, E. (2014). Assessing participatory processes and outcomes in agricultural research for development from participants' perspectives. Fournal of Rural Studies 35:91-100. doi:10.1016/j.jrurstud.2014.04.010.

Kamai, N., Gworgwor, N. A. and Wabekwa, J. W. (2014). Varietal trials and physiological components determining yield differences among cowpea varieties in semiarid zone of Nigeria. ISRN Agronomy. doi:https://doi.org/10. $1155 / 2014 / 925450$.

Kane, D., Rogé, P. and Snapp, S. S. (2016). A systematic review of perennial staple crops literature using topic modeling and bibliometric analysis. PLoS One 11:e0155788.

Kante, M., Rattunde, H. F. W., Leiser, W. L., Nebié, B., Diallo, B., Diallo, A., Touré, A. O., Weltzien, E. and Haussmann, B. I. (2017). Can tall guinea-race sorghum hybrids deliver yield advantage to smallholder farmers in West and Central Africa? Crop Science 57:833-842.

Keeley, J. and Scoones, I. (2000). Knowledge, power and politics: The environmental policy-making process in Ethiopia. The Fournal of Modern African Studies 38:89-120.

Kell, D. B. (2012). Large-scale sequestration of atmospheric carbon via plant roots in natural and agricultural ecosystems: Why and how. Philosophical Transactions Royal Society of Britian Biology 367:1589-1597.

Kfir, R. (1997). Competitive displacement of Busseola fusca (Lepidoptera: Noctuidae) by Chilo partellus (Lepidoptera: Pyralidae). Annals of the Entomological Society of America 90:619-624.

Kimani, E. N., Wachira, F. N. and Kinyua, M. G. (2012). Molecular diversity of Kenyan Lablab bean (Lablab purpureus (L.) Sweet) accessions using amplified fragment length polymorphism markers. American fournal of Plant Science 3:313-321.

Kimani, P. M. (2000). Pigeon pea breeding: Objectives, experiences, and strategies for Eastern Africa. In Status and Potential of Pigeon Pea in Eastern and Southern Africa: Proceedings of a Regional Workshop, 12-15 Sept. 2000, Nairobi, Kenya (Eds S. N. Silim, G. Mergeai and P. M. Kimani). B-5030 Gembloux, Belgium: Gembloux Agricultural University; and Patancheru 502 324, International Crops Research Institute for the Semi-Arid Tropics (ICRISAT).

Kimber, C., Dahlberg, J. and Kresovich, S. (2013). The gene pool of Sorghum bicolor and its improvement. In Genomics of the Saccharinae, vol. 11, 23-41 (Ed A. H. Patterson):. doi:10.1007/978-1-4419-5947-82.

Kristjanson, P., Okike, I., Tarawali, S., Singh, B. B. and Manyong, V. (2005). Farmers' perceptions of benefits and factors affecting the adoption of improved dual-purpose cowpea in the dry savannas of Nigeria. Agricultural Economics 32:195-210. 
Labeyrie, V., Deu, M., Dussert, Y., Rono, B., Lamy, F., Marangu, C., Kiambi, D., Calatayud, C., Coppens d'Eeckenbrugge, G., Robert, T. and Leclerc, C. (2016). Past and present dynamics of sorghum and pearl millet diversity in Mount Kenya region. Evolutionary Applications 9:1241-1257.

Larkin, P. J., Newell, M. T., Hayes, R. C., Aktar, J., Norton, M. R., Moroni, S. J. and Wade, L. J. (2014). Progress in developing perennial wheats for grain and grazing. Crop \& Pasture Science 65:1147-1164. doi:10.1071/CP13330.

Lawn, R. J. (1989). Agronomic and physiological constraints to the productivity of tropical grain legumes and prospects for improvement. Experimental Agriculture 25:509-528.

Malawi Guide to Agriculture (2010). Government of Malawi, Lilongwe, Malawi. https://trove.nla.gov.au/version/ 13320976

Mandal, R. G., Vidyabhushanam, R. V. and Santhanam, V. (1965). Ratooning in hybrid sorghum gives more food and fodder. Indian Farming 15:30-31.

McGuire, S. (2002). Farmers' views and management of sorghum diversity in Western Harerghe, Ethiopia: Implications for collaboration with formal breeding. In 'Collaborative Plant Breeding: Integrating Farmers' and Plant Breeders' Knowledge and Practice', 107-136 (Eds D. Cleveland and D. Soleri). Wallingford, Oxon: CABI.

Mekbib, F. (2009). Farmers' breeding of sorghum in the centre of diversity, Ethiopia: I. Socio-Ecotype differentiation, varietal mixture and selection efficiency. Maydica 54:25-37.

Ministry of Agriculture and Food Security (MoAFS) (2012). Agricultural Production Estimates Survey (APES) Crop Production and Area Harvested by Extension Planning Area. Government of Malawi, Lilongwe, Malawi.

Mishra, A., Hansen, J. W., Dingkuhn, M., Baron, C., Traore, S. B., Ndiaye, O. and Ward, M. N. (2008). Sorghum yield prediction from seasonal rainfall forecasts in Burkina Faso. Agricultural and Forest Meteorology 148:1798-1814.

Mofokeng, M. A., Shimelis, H. and Laing, M. D. (2016). Constraints and varietal trait preferences of sorghum producers in South Africa. Journal of Tropical Agriculture 54:7-15.

Mohyuddin, A. I. and Greathead, D. J. (1970). An annotated list of the parasites of graminaceous stem borers in East Africa with a discussion of their potential in biological control. Entomophaga 15:241-274.

Montpellier Panel, The (2013). Sustainable Intensification: A New Paradigm for African Agriculture, London.

Moore, H. L. and Vaughan, M. (1994). Cutting down trees: Gender, nutrition, and agricultural change in the Northern Province of Zambia, 1890-1990. Social History of Africa. Portsmouth, NH, Heinemann.

Morris, G. P., Ramu, P., Deshpande, S. P., Hash, C. T., Shah, T., Upadhyaya, H. D., Riera-Lizarazu, O., Brown, P. J., Acharya, C. B., Mitchell, S. E. and Harriman, J. (2013). Population genomic and genome-wide association studies of agroclimatic traits in sorghum. Proceedings of the National Academy of Sciences 110:453-458.

Myaka, F. M., Sakala, W. D., Adu-Gyamfi, J.J., Kamalongo, D., Ngwira, A., Odgaard, R. and Høgh-Jensen, H. (2006). Yields and accumulations of $\mathrm{N}$ and $\mathrm{P}$ in farmer-managed intercrops of maize-pigeon pea in semi-arid Africa. Plant and Soil 285:207-220.

Ntare, B. R. and Williams, J. H. (1992). Response of cowpea cultivars to planting pattern and date of sowing in intercrops with pearl millet in Niger. Experimental Agriculture 28:41-48.

Omanga, P. A., Summerfield, R. J. and Qi, A. (1995). Flowering of pigeon pea (Cajanus cajan) in Kenya: Responses of early-maturing genotypes to location and date of sowing. Field Crops Research 41:25-34.

Orr, A., Kambombo, B., Roth, C., Harris, D. and Doyle, V. (2015). Adoption of integrated food-energy systems: Improved cook stoves and pigeon pea in southern Malawi. Experimental Agriculture 51:191-209.

Ortega, D. L., Waldman, K. B., Richardson, R. B., Clay, D. and Snapp, S. S. (2016). Sustainable intensification and farmer preferences for crop system attributes: Evidence from Malawi's Central and Southern regions. World Development 87:139-151.

Pachico, D. (2014). Towards appraising the impact of legume research: A synthesis of evidence. In Standing Panel on Impact Assessment (SPIA), CGIAR Independent Science and Partnership Council, Rome, Italy, 39 pp.

Paterson, A. H., Cox, T. S., Wegian, K. and Navarro, M. (2014). Viewpoint: Multiple-harvest sorghums toward improved food security. In Perennial Crops for Food Security, Proceedings of the FAO Expert Workshop, Food and Agricultural Organization, Rome, 90 pp.

Peter, B., Mungai, L., Messina, J. P. and Snapp, S. S. (2017). Nature-based agricultural solutions: Scaling perennial grains across Africa. Environmental Research 159:283-290.

Petersen, B. and Snapp, S. S. (2015). What is sustainable intensification: Views from experts. Land Use Policy 46:1-10. doi:10.1016/j.landusepol.2015.02.002.

Pingali, P. L. (2001). Meeting world maize needs: Technological opportunities and priorities for the public sector. CIMMYT 1999/2000 World Maize Facts and Trends.

Plucknett, D. L., Evenson, J. P. and Sanford, W. G. (1970). Ratoon cropping. Advances in Agronomy 22:285-330. 
Rao, P. S., Rathore, A. and Reddy, B. V. (2013). Interrelationship among biomass related traits and their role in sweet Sorghum cultivar productivity in main and ratoon crops. Sugar Technology 15:278-284.

Rasse, D. P., Rumpel, C. and Dignac, M. (2005). Is soil carbon mostly root carbon? Mechanisms for a specific stabilization. Plant and Soil 269:341-356.

Reddy, B. V., Sharma, H. C., Thakur, R. P., Ramesh, S., Rattunde, F. and Mgonja, M. (2006). Sorghum hybrid parents research at ICRISAT-strategies, status and impacts. Fournal of Semi-Arid Tropics Agricultural Research 2: $1-24$.

Rogé, P., Diarisso, T., Diallo, F., Boiré, Y., Goïta, D., Peter, B., Macalou, M., Weltzien, E. and Snapp, S. S. (2017). Perennial grain crops in the West Soudanian Savanna of Mali: Perspectives from agroecology and gendered spaces. International Journal of Sustainable Agriculture 15:555-574.

Rogé, P., Snapp, S. S., Kakwera, M. N., Mungai, L., Jambo, I. and Peter, B. (2016). Ratooning and perennial staple crops in Malawi. A Review. Agronomy for Sustainable Development 36(3). doi:10.1007/s13593-016-0384-8.

Rusinamhodzi, L., Makoko, B. and Sariah, J. (2017). Ratooning pigeon pea in maize-pigeon pea intercropping: Productivity and seed cost reduction in eastern Tanzania. Field Crops Research 203:24-32.

Sánchez, B., Rasmussen, A. and Porter, J. R. (2014). Temperatures and the growth and development of maize and rice: A review. Global Change Biology 20:408-417.

Sardana, V., Sharma, P. and Sheoran, P. (2010). Growth and production of pulses. Soils, Plant Growth and Crop Production $3: 378-416$.

Scoones, I. (2015). Transforming soils: Transdisciplinary perspectives and pathways to sustainability. Current Opinion in Environmental Sustainability 15:20-24.

Silim, S. N. and Omanga, P. A. (2001). The response of short-duration pigeon pea lines to variation in temperature under field conditions in Kenya. Field Crops Research 72(2), 97-108.

Simtowe, F., Shiferaw, B., Kassie, M., Abate, T., Silim, S., Madzonga, M., Muricho, G. and Kananji, G. (2010). Assessment of the current situation and future outlooks for the pigeon pea sub-sector in Malawi. International Crops Research Institute for the Semi-Arid Tropics, Patancheru, India.

Smaje, C. (2015). The strong perennial vision: A critical review. Agroecology and Sustainable Food Systems 39:471-499.

Smith, A., Snapp, S. S., Dimes, J., Gwenambira, C. and Chikowo, R. (2016). Doubled-up legume rotations improve soil fertility and maintain productivity under variable conditions in maize-based cropping systems in Malawi. Agricultural Systems 145:139-149.

Smith, R. J. (1929). Tree Crops: A Permanent Agriculture, Friends of the Land, Devin-Adaid, New York, NY, USA, 410 pp.

Snapp, S. S., Blackie, M. J., Gilbert, R. A., Bezner-Kerr, R. and Kanyama-Phiri, G. Y. (2010). Biodiversity can support a greener revolution in Africa. Proceedings of the National Academy of Sciences 107:20840-20845.

Snapp, S. S., Rohrbach, D. D., Simtowe, F. and Freeman, H. A. (2002). Sustainable soil management options for Malawi: Can smallholder farmers grow more legumes? Agriculture Ecosystems and Environment 91:159-174.

Snapp, S. S. and Silim, S. N. (2002). Farmer preferences and legume intensification for low nutrient environments. Plant and Soil 245:181-192. doi:10.1023/A:1020658715648.

Stamp, P. and Visser, R. (2012). The twenty-first century, the century of plant breeding. Euphytica 186:585-591. doi:10.1007/s10681-012-0743-8.

Tayo, T. O. (1985). Assessment of the effect of ratooning pigeon pea (Cajanus cajan (L.) Millsp.) in the lowland tropics. The fournal of Agricultural Science 104:589-593.

Tomlinson, I. (2013). Doubling food production to feed the 9 billion: A critical perspective on a key discourse of food security in the UK. Fournal of Rural Studies 29:81-90.

Valbuena, D., Erenstein, O., Tui, S. H. K., Abdoulaye, T., Claessens, L., Duncan, A. J., Gérard, B., Rufino, M. C., Teufel, N., van Rooyen, A. and van Wijk, M. T. (2012). Conservation agriculture in mixed crop-livestock systems: Scoping crop residue trade-offs in Sub-Saharan Africa and South Asia. Field Crops Research 132:175-184.

Valenzuela, H. and Smith, J. (2002). Pigeon pea. Sustainable Agriculture Green Manure Crops. Cooperative Extension Service. College of Tropical Agriculture and Human Resources, University of Hawai'I, Manoa, HI.

Van Tassel, D. L., DeHaan, L. R. and Cox, T. S. (2010). Missing domesticated plant forms: Can artificial selection fill the gap? Evolutionary Applications 3:434 452.

Vaughan, M. (1987). The Story of an African Famine: Gender and Famine in Twentieth-Century Malawi. New York: Cambridge University Press.

Vavilov, N. I. (1934). Soviet scientific plant industry during the period of soviet reconstruction 1930-1933. Bulletin of Applied Botany Leningrad, Series A 10:5-23. 
Vico, G. and Brunsell, N. A. (2018). Tradeoffs between water requirements and yield stability in annual vs. perennial crops. Advances in Water Resources. 112:189-202.

Vinutha, K. S., Kumar, G. A., Blümmel, M. and Rao, P. S. (2017). Evaluation of yield and forage quality in main and ratoon crops of different sorghum lines. Tropical Grasslands-Forrajes Tropicales 5:40-49.

Waldman, K. B., Ortega, D. L., Richardson, R. B. and Snapp, S. S. (2017). Estimating demand for perennial pigeon pea in Malawi using choice experiments. Ecological Economics 131:222-230.

Willey, R. W., Rao, M. R., Reddy, M. S. and Natarajan, M. (1982). Cropping systems with sorghum. In Sorghum in the Eighties: Proceedings of the International Symposium on Sorghum, 2-7 November, 1981. International Crops Research Institute for the Semi-Arid Tropics (ICRISAT), Andhra Pradesh, India, pp. 477-490.

Wilson, K. S. L. (2011). Sorghum ratooning as an approach to manage covered kernel smut and the stem borer Chilo Partellus. PhD. Thesis. University of Greenwich, London, UK.

Wood, L. and Moriniere, L. (2013). Malawi climate change vulnerability assessment annex D. Crop Phenology. USAID - African and Latin American Resilience to Climate Change (ARCG).

Zhao, X., Zhang, T., Huang, L., Wu, H., Hu, F., Zhang, F., Zhu, L. and Fu, B. (2012). Comparative metabolite profiling and hormone analysis of perennial and annual rice. Fournal of Plant Biology 55:73-80. doi:10.1007/s12374011-9192-5. 